\title{
Great Power Game around the Chemical Weapons Attacks in Syria and the New Norm on Banning Chemical Weapons
}

\author{
Hanjing Yue*, Ying Zhu
}

Anhui University of Finance and Economics, Anhui, China

DOI: $10.36347 / \mathrm{sjebm} .2020 . \mathrm{v} 07 \mathrm{i} 09.004$

| Received: 13.09.2020 | Accepted: 21.09.2020 | Published: 24.09.2020

*Corresponding author: Hanjing Yue

Abstract

Review Article

Early in the Syrian conflict, US President Barack Obama drew a "red line" for the Syrian government on the issue of chemical weapons. The "red line" implies a new norm for the prohibition of chemical weapons: If a government uses chemical weapons against its civilians, other countries can strike it with force. After reports of chemical weapons attacks in Syria, the Obama administration's attempt to implement the "red line" shows that "strike by force" in its proposed norm can be carried out without authorization from the United Nations Security Council. Although the smooth implementation of the "chemical weapons for peace" plan put forward by Russia had avoided the implementation of the "red line" by the United States, it showed that Russia had in action acquiesced in the new norm of banning chemical weapons. From February 2017 to April 2018, Russia and other countries vetoed six draft resolutions submitted to the UN Security Council by the US, Britain, France and other countries related to the investigation of the new chemical attacks in Syria. However, despite the opposition of Russia and other countries, the United States, Britain and France insisted that the Syrian government had used chemical weapons against civilians and launched two missile attacks against it. The attack carried out the new norm and further clarified the scale of "military strikes" in the new norm. With regard to the proposed new norm, China and Russia still insist that military strikes need to be authorized by the UN Security Council, and oppose the use of false evidence to abuse the new norm. The new international norm of chemical prohibitions proposed by the United States, Britain, France and other countries are essentially a new development of the theory of humanitarian intervention. The game between the great powers around the chemical weapons attacks in Syria embodies the international normative question of "which is more important, sovereignty or human rights".

Keywords: Syria; chemical weapons attack; great power game; international norms; US; Russia.

Copyright @ 2020: This is an open-access article distributed under the terms of the Creative Commons Attribution license which permits unrestricted use, distribution, and reproduction in any medium for non-commercial use (NonCommercial, or CC-BY-NC) provided the original author and source are credited.

\section{INTRODUCTION}

In the situation that the attempts to implement R2P and copy the "Libyan model" in Syria on the pretext of humanitarian crises were blocked, the United States, Britain, France and other countries had also focused their attention on the chemical attacks in Syria, making unilateral military strikes against the Syrian government on the pretext that the Syrian government had carried out chemical attacks on its civilians. However, a series of intervention measures taken by the United States, Britain, France and other countries under the pretext of chemical weapons attacks in Syria had met with strong opposition from China, Russia and other countries. As a result, the great powers in the Syrian conflict launched a fierce game around the Syrian chemical weapons attack. The academic circles analyze the game carried out by the great powers around the chemical weapons attack in Syria mostly from the perspective of geopolitics and power politics
[1] but the results of the analysis of this game from the level of international norms seem to be very few, with most of the relevant achievements having focused on the legality of missile attacks by the United States (Britain and France) against Syria [2] and there being few studies on how the game affects the creation of relevant international norms. What is the impact of the great power game in the Syrian chemical weapons attacks on the level of international norms? What international norms are embodied in the game? Such questions need to be further studied. The study of such questions will not only help people to grasp the development process and prospects of the Syrian conflict as a whole, but also provide some reference for a big power to maintain its diplomatic discourse system and international discourse power in the Syrian conflict. This paper compares and analyzes the games carried out by the great powers around the chemical weapons attacks in Syria in different historical stages, and 
discusses the influence of the game on the level of international norms and the international normative questions manifested by the game.

The main body of this paper is divided into four parts: The first part briefly introduces the current international norms on prohibition of chemical weapons; The second part analyzes the influence of the early "game" on the emergence of the new international norm on prohibition of chemical weapons. The third part discusses the game between the big powers in the practice of the new norms around the new chemical attacks. The fourth part reveals the essence of the new norm on prohibition of chemical weapons.

\section{Current International Norms on the Prohibition of Chemical Weapons}

Chemical weapons taboos have been around for more than a century because such weapons are highly lethal and are used without distinguishing between military targets and civilians and are an inherent threat to civilians. The 1925 Geneva Convention forbids the use of poison gas as a weapon of war for the first time. The Chemical Weapons Convention, which was opened for signature in 1993 and entered into force in 1997, went even further by outlawing the production, stockpiling, transfer and use of chemical weapons. The State that ratified the convention undertook to destroy its existing stocks. The Organization for the Prohibition of Chemical weapons is responsible for the implementation of the convention [3].

The use of chemical weapons is prohibited in a number of international treaties, including the Hague Declaration concerning Asphyxiating Gases, the Geneva Gas Protocol, the Chemical Weapons Convention (CWC) and the Statute of the International Criminal Court. The use of chemical weapons violates the Geneva Conventions and their additional protocols, the Hague regulations and international humanitarian law. The use of chemical weapons also violates international criminal law. The Rome Statute of the International Criminal Court classifies the use of chemical weapons in international and non-international armed conflicts as war crimes. The use of chemical weapons in widespread and systematic attacks against the civilian population is a crime against humanity. A chemical attack may be sufficient to constitute a crime against humanity or a crime of genocide. Crimes against humanity and genocide are subject to universal jurisdiction, which means that they can be prosecuted by any State regardless of the location or nationality of the perpetrators or victims. The reason for universal jurisdiction over crimes against humanity and genocide is that such crimes are an insult to the international community as a whole. The parties to the Geneva Convention and its additional protocols have not only a clear obligation to comply with the treaty, but also an obligation to ensure that those obligations are respected.
However, the specific actions to implement this obligation are not specified in the Convention and the Protocol, that is, it does not specify what measures other States should take against violators [4]. In the process of dealing with chemical weapons attacks in Syria, especially in punishing those who are believed by the United States, Britain and France to initiate chemical weapons attacks, the three countries have tried to create new norms for banning chemical weapons.

\section{The Emergence of the Game and the New Norm on Prohibition of Chemical Weapons}

As Syria is believed to have a large number of chemical weapons, shortly after the Syrian conflict broke out, the United States and other Western countries tried to use chemical weapons to intervene in Syria. As early as August 20, 2012, in the absence of reports of chemical weapons attacks in Syria, US President Obama declared: We have made it clear to the Assad regime and other participants on the ground that our red line is that we are beginning to see a large number of chemical weapons moving around or being used [5].

The message conveyed by Obama's words was that if the Syrian government moved around or uses chemical weapons, it would cross the red line, that is, it would be attacked by force. Obama's "moving chemical weapons around" here actually refers to the Syrian government's deliberate transfer of chemical weapons to Hezbollah guerrillas in Lebanon. Based on this, one can infer that Obama's red line is based on the normative assumption that if a government hands over chemical weapons to terrorists or uses them directly, other countries can attack them by force. Given the situation in Syria at that time, Obama's "use of chemical weapons" should refer to the use of the weapon on the opposition (Obama regarded them as civilians and the Syrian government as terrorists). However, it is impossible to infer from the red line whether such a military strike requires the authorization of the UN Security Council. But, as soon as the Syrian chemical weapons attack was reported and Obama's red line thus faced the test of practice, the answer to this question gradually became clear.

On December 23, 2012, a chemical weapons attack occurred in Khalidiya, Homs, Syria. This is the first record of the use of chemical weapons in Syria. On August 21, 2013, Eastern Ghouta and Moadamiya outside Damascus were attacked by sarin, causing a large number of civilian casualties [6]. For the two attacks, the United States and its allies, without any concrete evidence, blamed the Syrian government forces and believed that Syria had crossed the red line and intended to carry out military attacks on targets in Syria.

However, the threat from the United States and other countries has not received wide international 
support. Let's not say that the Syrian government did not admit that its army used chemical weapons. Iran, Russia and other countries also believed that there was no sufficient evidence to prove that the attack was committed by Syrian government forces, so it was groundless to use force against Syria. Although President Obama's military strike plan was supported by French President Hollande, on August 30, 2013, the British Parliament unexpectedly voted against Britain's participation in the planned US led military operation. Although the Arab League said it would support military action, it would only do so if it was authorized by the United Nations and its members Egypt, Iraq, Lebanon, Tunisia and Algeria claimed to be against military intervention in Syria [7]. Following a vote in the British Parliament, Obama also announced that he intended to gain congressional support for military strikes, although this was not necessary under the US Constitution. But Obama has not received strong support either in Congress or among the American public [8].

Judging from the reaction of the Obama administration and the British and French governments to the initial Syrian chemical weapons attack, when they threatened to use force against Syria to demonstrate their determination to implement the red line, no obvious efforts have been made to get authorization from the United Nations Security Council, although they tried to get authorization from their own Congress. Therefore, the "military strike" in the normative assumption introduced above can be carried out without the authorization of the Security Council. In this way, based on Obama's red line and its performance in trying to implement the red line, one can more accurately draw such a normative assumption: If a government uses chemical weapons against its civilians, then other countries can use force against them even without the authorization of the Security Council.

When President Obama hesitated to use force against the Syrian government, Russia put forward the chemical weapons for peace plan, and obtained the agreement of the United States and Syria. The Syrian government sent a letter to the UN Secretary General on September 12, 2013, saying that Assad had signed a presidential decree allowing Syria to join the chemical weapons convention. Normally, the treaty enters into force 30 days after the deposit of its instrument of ratification, but Syria indicated in its letter that it would begin to fulfil its treaty obligations immediately [9]. On September 14, the United States and Russia announced that they had reached a framework agreement on the destruction of Syrian chemical weapons and the destruction of Syria's chemical weapons stockpiles and production facilities. Syria agreed to sign the Chemical Weapons Convention. On September 27, the UN Security Council adopted resolution 2118, which provides more explicit and authoritative provisions on
Syria's chemical weapons. The organization for the prohibition of chemical weapons was awarded the 2013 Nobel Peace Prize for its contribution to the issue of chemical weapons in Syria [10].

Chemical weapons for Peace shows that Obama did not really want to use force against the Syrian government. His red line was more to support the Syrian opposition, but it also showed his judgment that the Syrian government was running out of time, worried that it might be desperate to use chemical weapons, or it might not be able to effectively control its chemical weapons and make it flow into the hands of terrorists identified by the United States. Of course, Obama's self-declared red line seemed too arbitrary, because according to existing international norms, even if the Syrian government does use chemical weapons in the Syrian conflict, without the authorization of the Security Council, no other country or group of countries has the right to use force against it. However, Obama's red line also has obvious rewards, because the existence of the red line forced the Syrian government to agree to accede to the Chemical weapons Convention and destroy its chemical weapons under international supervision, which had greatly reduced the loss of the Obama administration's international credibility due to its failure to implement his red line. And, more importantly, Obama's red line and its attempted enforcement showed and reinforced the new norm that the United States and other Western countries were trying to advocate against chemical weapons: If a government uses chemical weapons against its own civilians, even anti-government forces, then other countries have the right to use force against its government, even if it is not authorized by the United Nations Security Council.

Although Russia questioned the Western judgment about the Syrian government's use of chemical weapons, it had not shown any obvious opposition to Obama's red line. Even if we assume that Russia verbally opposed Obama's red line, since it mediated the exchange of chemical weapons for peace, at least in terms of behavioral logic, it not only acquiesced in the use of chemical weapons by the Syrian government, but also acquiesced in the new norm of international prohibition of chemical weapons advocated by the United States and other countries. Russia's proposal of chemical weapons for peace is tantamount to saying to the United States, Britain and France: Stop fighting the Syrian government, I advised it to give up its chemical weapons, and it agreed. However, countries, including Russia, knew that the United States, Britain and France threatened to use force against the Syrian government not because it possessed chemical weapons, but because they believed that the Syrian government had used chemical weapons. Therefore, Russia's exchange of chemical weapons for peace also illustrates the following two points: First, Russia acquiesced that the Syrian government 
committed a "crime" (the use of chemical weapons) and violated the "law" (the new norm advocated by the United States, Britain and France); Second, the Syrian government atoned for its "crimes" by "giving up chemical weapons". Why could "giving up chemical weapons" atone for its "crimes"? Because if the Syrian government abandoned chemical weapons, the movement and use of chemical weapons would become very difficult or even impossible, that is to say, it would be extremely difficult for the Syrian government to cross the red line in the future. In short, the "exchange of chemical weapons for peace" not only did not deny the rationality of the red line, but also strengthens its reasonableness. Thus, it is tantamount to accepting the normative assumption behind the red line (the new norm on banning chemical weapons): If a government uses chemical weapons against its civilians, then other countries can use force against them without the authorization of the Security Council.

The Obama administration's red line and its efforts to implement the red line had made the new norm of the ban on chemical weapons more and more clear. "Chemical weapons for peace" was a further strengthening of the new norm on the prohibition of chemical weapons. However, after all, the Obama administration had not really implemented its red line, so an important aspect of the new norm on the prohibition of chemical weapons is not clear enoughthe scale and intensity of the "military strike". The "exchange of chemical weapons for peace" only brought the issue of chemical weapons in Syria to the end of one stage and did not completely solve the problem. When the incident of chemical weapons attack in Syria was reported again, the United States, Britain, France and other countries not only continued to talk about the issue of chemical weapons on the international platform such as the United Nations, but also practiced the new norm of banning chemical weapons twice in action advocated by them. Through the two practices of the new norm, the scale and intensity of "military strikes" in the new norm have gradually become clear.

\section{"Game" and the Practice of the New Norm on Banning Chemical Weapons}

The above-mentioned new norm, which is strongly advocated by the United States, Britain, France and other countries, provide a basis for them to use force against the Syrian government to achieve some of their political goals. If military action is to be taken openly against the Syrian government in accordance with that new norm, it is clear that evidence of the use of chemical weapons by the Syrian government needs to be provided, and this evidence must be recognized by all permanent members of the United Nations Security Council. It is not too difficult for the United States, Britain and France to obtain "evidence" of the use of chemical weapons, but the key is that such evidence should be recognized by Russia and China. It is in terms of the authenticity of the evidence and the impartiality of the evidence providers that the United States, Britain and France have launched a fierce game with China, Russia and other countries in the United Nations Security Council.

In a little more than a year from February 2017 to April 2018, Russia vetoed the draft resolution on chemical weapons in Syria proposed by the United States, Britain, France, Japan and other countries six times in the United Nations Security Council. The main information of the relevant draft resolutions is shown in the following table [11].

\begin{tabular}{|c|c|c|c|c|}
\hline Date & Draft & Agenda Item & Against & Abstentions \\
\hline $\begin{array}{l}28 \text { Feb. } \\
2017\end{array}$ & $\mathrm{~S} / 2017 / 172$ & $\begin{array}{l}\text { - Acknowledges findings of JIM report; use of chemical } \\
\text { weapons by the Syrian Armed Forces and ISIL } \\
\text { - Calls for Tribunal to prosecute guilty parties } \\
\text { - Sanctions against identified individuals }\end{array}$ & $\begin{array}{l}\text { Russia, } \\
\text { China, } \\
\text { Bolivia }\end{array}$ & $\begin{array}{l}\text { Egypt, Ethiopia, } \\
\text { Kazakhstan }\end{array}$ \\
\hline $\begin{array}{l}12 \\
\text { April } \\
2017\end{array}$ & $\mathrm{~S} / 2017 / 315$ & $\begin{array}{l}\text { - Condemns use of chemical weapons } \\
\text { - Access to the OPCW FFM and JIM to all relevant } \\
\text { information to investigate attacks }\end{array}$ & $\begin{array}{l}\text { Russia, } \\
\text { Bolivia }\end{array}$ & $\begin{array}{l}\text { China, Ethiopia, } \\
\text { Kazakhstan }\end{array}$ \\
\hline $\begin{array}{l}24 \text { Oct. } \\
2017 \\
\end{array}$ & $\mathrm{~S} / 2017 / 884$ & - Renew mandate of JIM for period of 1 year & $\begin{array}{l}\text { Russia, } \\
\text { Bolivia }\end{array}$ & $\begin{array}{l}\text { China, } \\
\text { Kazakhstan }\end{array}$ \\
\hline $\begin{array}{l}16 \text { Nov. } \\
2017\end{array}$ & $\mathrm{~S} / 2017 / 962$ & $\begin{array}{l}\text { - Condemns use of chemical weapons by Syrian Army } \\
\text { - Taking note of JIM findings } \\
\text { - Renew mandate of JIM for } 12 \text { months }\end{array}$ & $\begin{array}{l}\text { Russia, } \\
\text { Bolivia }\end{array}$ & China, Egypt \\
\hline $\begin{array}{l}17 \text { Nov. } \\
2017\end{array}$ & $\mathrm{~S} / 2017 / 970$ & - Renew mandate of JIM for 30 Days & $\begin{array}{l}\text { Russia, } \\
\text { Bolivia }\end{array}$ & China \\
\hline $\begin{array}{l}10 \mathrm{Apr} . \\
2018\end{array}$ & $\mathrm{~S} / 2018 / 321$ & $\begin{array}{l}\text { - Condemn the repeated Syrian chemical weapons attacks } \\
\text {-Establish a United Nations independent investigation } \\
\text { mechanism, to determine the parties responsible for the } \\
\text { chemical weapons attacks in Syria }\end{array}$ & $\begin{array}{l}\text { Russia, } \\
\text { Bolivia }\end{array}$ & China \\
\hline
\end{tabular}


The Game on the Authenticity of Evidence and the Practice of the New Norm by the United States

On February 28, 2017, in an explanatory statement after voting on the draft (see table above), Savronkov, deputy permanent representative of Russia to the United Nations, said that the draft submitted by the United States, Britain and France was "based on the concept of anti-Syrian regime in western capitals" and that the investigation report it was based on was not objective, comprehensive or fair, and that the drafters of the draft needed a joint investigation mechanism. Its sole purpose is to impose responsibility for the use of chemical weapons on the Assad government, thereby creating more justification for regime change in Damascus. In his explanatory statement, Liu Jieyi, permanent representative of China to the United Nations, expressed doubts about some of the statements in the draft, saying that "there must be accurate, detailed and solid evidence that can really stand the test of history". He also reminded us anxiously that "we all remember that the existence of so-called large-scale weapons of destruction was used to launch a war in the past, bringing endless suffering to the people of the Middle East" [12].

Obviously, Russia and China voted against the draft resolution of 28 February out of a common concern: The United States, Britain and France, on the grounds of the so-called findings of questionable investigation (the Syrian government used chemical weapons to attack its civilians), carry out regime change in Syria by force, or put on a cloak of legitimacy for other forms of interference. The draft resolution submitted by the United States, Britain and France is also an attempt to promote chemical weapons taboos (norms), that is, if a government uses chemical weapons against its civilians, then the government should be punished. China and Russia did not oppose this taboo, but they opposed some countries using false excuses to crack down on the Syrian government in order to achieve their own political goals. China and Russia also opposed illegal punishment under the pretext of the issue of chemical weapons, such as a strike by force without the authorization of the Security Council. In fact, on the issue of chemical weapons in Syria, the game between China and Russia, especially Russia, and the West in the Security Council focuses on these two points: Whether the evidence is credible and whether the punishment is legal. However, despite the opposition of China and Russia, the United States had decided to put aside the Security Council and practice its own new norm through practical actions in accordance with its own understanding of the authenticity of the attacks.

It was reported that on April 4, 2017, the Khan Shaykhoun area in Idlib province had been attacked by sarin gas. Subsequently, on 6 April 2017, the United States attacked air base in Shailat, Syria, using Tomahawk cruise missiles. The United States, without sufficient evidence, said the Assad regime launched a chemical weapons attack from the base on April 4 . [13]Russia and other countries severely condemned the missile attacks by the United States. At the Security Council meeting held on April 7 to discuss the US air strike on the base in Shailat, Savronkov, deputy permanent representative of Russia to the United Nations, criticized the attack as a "flagrant violation of international law" and an act of aggression, saying that it "will only encourage terrorism". Russia also accused "the OPCW fact-finding mission of not working dutifully" and "not looking at the information and evidence in the area where the incident occurred", preferring to use statements from opposition groups and "a series of non-governmental organizations with a highly dubious reputation to guide their work" [14]. On 12 April, the Security Council held a meeting to vote on the draft resolution submitted by the United States, Britain and France (see table above), and Russia vetoed it. In an explanatory speech after the vote, Russian representative Savronkov said that the draft "adopts an one-sided preconceived view of anti-Syria" and that without the consent of the Security Council the United States attacked Syrian air bases before the international investigation was launched, which violated international law, and "a vote in favor of the three-nation western draft resolution would legitimize these illegal acts" [15].

\section{The Game on Whether to Extend the Mandate to the Joint Investigation Mechanism and the Practice of the New Norm by the United States, Britain and France}

Soon after, the United States, Britain, France and other countries engaged in a fierce game with Russia and other countries on the Security Council on whether to extend the mandate of the joint investigation mechanism. In order to determine whether chemical weapons were used in the reported attacks, and if so, what types of chemical weapons were used, and other relevant details of the attack, the Organization for the Prohibition of Chemical Weapons Fact-finding Mission (OPCW Fact-Finding Mission) was established in 2014. However the fact-finding mission has no right to investigate which party is responsible for the use of chemical weapons. In order to make up for this deficiency, the OPCW-UN Joint Investigative Mechanism was established in 2015 in accordance with UN Security Council Resolution 2235. Its mandate was to investigate the perpetrators of the use of chemical weapons in Syria identified by the fact-finding mission. Its term of office must be extended annually by the Council, otherwise it cannot continue to operate [16].

In October and November 2017, Russia and Europe and the United States engaged in another fierce game in the Security Council on whether to extend the mandate of the joint investigation mechanism. Russia vetoed the relevant draft resolutions submitted by Europe and the United States three times (see table 
above). The core reason for veto was that the joint investigation mechanism had become a provider or even maker of false reasons for actions of Europe and the United States. Nebenzia, representative of Russia, pointed out in his statement that "the mechanism is not up to its mandate and will only provide an excuse for inappropriate political purposes", that it "blindly endorses baseless accusations against Syria over the past two years" and that there are "systematic flaws" in its fact-finding work, and that extending the mandate of such a body would weaken the authority of the Security Council [17].

Although the mission of the joint investigation mechanism in Syria had been suspended, the chemical weapons attacks in Syria had not stopped. In response to the new chemical weapons attacks, Western countries once again engaged in fierce confrontation with Russia and other countries on how to deal with them.

On 1 February 2018, the third chemical weapons attack of the year was reported in Duma, Damascus. The two previous attacks took place on January 13 and 22, respectively. Chlorine was used in all the attacks, the report said. On April 7, 2018, there were reports of a large-scale chemical weapons attack in the town of Duma, on the outskirts of Damascus, Syria, killing at least dozens of civilians. Earlier, it was reported that a smaller chlorine attack occurred in the Duma on 7 and 11 March. [18]However, not to mention the identification of the attackers, there were serious differences in the international community as to whether the attacks actually had took place.

On April 10, 2018, the United Nations Security Council voted on three draft resolutions to address the chemical weapons attacks in Syria. Russia vetoed a draft resolution submitted by the United States (see table above), which proposes the creation of an independent United Nations investigation mechanism with a mandate of one year to investigate those responsible for the use of chemical weapons in Syria. A draft resolution from Russia proposed the establishment of a similar body in which the United Nations Security Council rather than the investigative body would finally identify those responsible, but failed to get a sufficient number of votes to pass. Russia's second draft resolution urged the fact-finding mission of the Organization for the Prohibition of Chemical weapons to investigate the events of 7 April and proposed to provide Russian military protection to investigators, but it was not approved by a sufficient number of votes. The representative of Russia pointed out that the independent investigation mechanism proposed by the United States was no different from the original mechanism and nothing more than a "puppet in the hands of anti-Damascus forces" and that "the perpetrators have been identified before the investigation ant they just want to use a mechanism to get the excuse they need to intervene from the white helmet. The Russian representative further pointed out that the United States and Europe, knowing full well that their draft could not be passed, asked for a vote here because they wanted a vetoed result so that "the use of force against Syria can be justified together with other reasons" [19].

The development of the matter was indeed as judged by the Russian representative. A few days later, on April 14, the United States, together with France and Britain, launched missile attacks on the Assad regime of Syria. The attack was said to be a response to the chemical weapons attack on April 7. There were said to be three targets of the air raid: 1.Scientific research facilities in Damascus for the production of chemical and biological weapons; 2.A chemical weapons storage facility west of Homs;3.A chemical weapons equipment warehouse and a command post near Homs [20].

The missile attacks by the United States, Britain and France were strongly opposed by Russia, Iran, Syria and other countries. On April 14, 2018, Russia asked the Security Council to hold an emergency meeting to discuss the aggression of the United States and its allies against Syria. At the meeting, the permanent representative of Russia to the United Nations, Nebenzya, read out Putin's statement on the missile attack on Syria. The statement said that the attack was an "act of aggression against a sovereign country without the permission of the UN Security Council" and "violated the Charter of the United Nations and the norms and principles of international law". Putin's statement also condemned the so called chemical weapons attack on which the West launched the missile attack against Syria as false, because "after visiting the scene of the alleged incident, Russian military experts found no traces of chlorine or any other toxic substances. None of the local residents can confirm that such an attack has taken place" [21]. In his speech at the meeting, Ma Zhaoxu, permanent representative of China to the United Nations, pointed out: "We advocate respect for the sovereignty, independence, unity and territorial integrity of all countries. Any unilateral military action that bypasses the Security Council violates the purposes and principles of the Charter of the United Nations, violates international law and the basic norms of international relations, and will bring new and complex factors to the settlement of the Syrian issue.” Ma Zhaoxu also called for a "comprehensive, impartial and objective investigation" into the suspected chemical weapons attack in Syria, and that "no party shall prejudge the outcome" until the investigation concludes that it can "stand the test of history". The statement made by the representative of China was intended because "in both cases, the air strikes were carried out before the factfinding mission investigated the incident and reported the results" [22]. The representative of Russia pointed out bluntly: "They not only put themselves above international law, but also tried to rewrite international 
law. They violated international law and tried to convince everyone that their actions were legitimate. The representative of the United Kingdom put forward three reasons for missile attacks based on the concept of humanitarian intervention. They are trying to replace the Charter with them" [23]

As mentioned earlier, former US president Barack Obama did not strike Syria by force after a chemical weapons attack in 2013, although he earlier declared that such an attack would cross the red line of the United States. But President Trump has twice taken practical actions to show that he is willing to punish the Assad regime to enforce the red line. At the same time, more importantly, Trump's implementation of the red line has further strengthened and clarified the norm advocated by the United States and other countries. As pointed out in the above analysis, the international norm advocated by the Obama administration through the red line and its attempt to implement the red line is that if a government uses chemical weapons against its civilians, other countries can use force against them without the authorization of the Security Council. However, it is difficult to infer the specific target, scale and intensity of the "armed strike". The two missile attacks on Syria by the United States alone and jointly with Britain and France have clarified the "armed strike" here. The "armed strike" here refers to a small-scale and shortlasting force strike, and the targets are the so-called military bases that launch chemical weapons attacks, the places where chemical weapons are developed or stored, and so on. In other words, the "armed strike" here is a relatively limited force strike, and the direct purpose is not regime change.

\section{The Essence of the New Norm on Prohibition of Chemical Weapons Advocated by the United States, Britain and France}

As pointed out above, the new norm for the international prohibition of chemical weapons advocated by the United States, Britain and France is that if a government uses chemical weapons against its civilians, other countries can carry out limited armed strikes against them, even if they are not authorized by the United Nations Security Council. If you ask: Why should a country be attacked by force when it uses chemical weapons against its civilians? The answer to this question will involve the reasons why chemical weapons have been banned by the international community, which in turn will definitely be linked to humanitarianism. After the attack, the United States, Britain and France all said that their air strikes were aimed at preventing the Assad regime from continuing to use chemical weapons against the Syrian people [24] (this is certainly not the real purpose, but we are only thinking about it here at the normative level). Therefore, the use of force against a government under the pretext of the use of chemical weapons remains fundamentally a form of humanitarian intervention. No wonder the participating countries claimed the legitimacy of the air strikes of April 2018 and accepted a common reasonhumanitarian intervention [25]. And "this is the first time in history that the United States and Britain have jointly used the legal argument of humanitarian intervention to justify the use of force" [26]. Therefore, it can be said that the new international norm on the prohibition of chemical weapons initiated by the United States, Britain and France is essentially a new development of the theory of humanitarian intervention.

However, as far as the missile attacks of the United States, Britain and France are concerned, apart from the traditional challenge of "not authorized by the United Nations Security Council", the logic of humanitarian intervention is also faced with a new challenge-the number of civilians killed and injured in chemical weapons attacks in Syria is far less than that caused by conventional weapons. For example, BBC reported that "more than 40 people were killed" [27] in the suspected chemical weapons attack on April 7, which triggered the second missile attack. In other words, this logic of humanitarian intervention does not meet the criteria for the quantity of harm. In that case, one can only say that, according to the "principle of charity" [28] on which an argument is constructed, this logic of humanitarian intervention relies more on the quality of the injury, that is, what causes the injury (the means to injure). The missile attacks by the United States, Britain and France show that, for them, the harm caused by the use of chemical weapons, even if it is small, is unforgivable.

Assume the Syrian Government used chemical weapons following its accession to the Chemical Weapons Convention in October 2013, thus violating its legal responsibilities under the Chemical Weapons Convention, United Nations Security Council Resolution 2118 and international humanitarian law. However, in the absence of further UN Security Council resolutions, there is no universally accepted international right to implement treaties or UN Security Council resolutions by military means. Even if a military strike against forces that have used chemical weapons against civilians is morally and politically justified it does not necessarily mean that such action is legal under international law. The United States, Britain and France tried to make it into customary international law by repeatedly practicing their new concept of humanitarian intervention and taking the "many supporters but few opponents" of missile attacks as the legal conviction [29]. As some scholars have pointed out: "It should also be borne in mind that State practice based on the legal conviction of opinio juris contributes to the emergence of new norms" [30].

\section{CONCLUSION}

The United States, Britain and France have been trying to use the Syrian chemical weapons attacks to intervene in Syria by force to crack down on the Syrian government in order to achieve their political 
goals. The Obama administration drew a red line for the Syrian government when there were no reports of chemical weapons attacks in Syria-"We are beginning to see a large number of chemical weapons moving around or being used." This red line sends a message to the outside world that if the Syrian government uses chemical weapons, then the United States and its allies will launch a military strike against it. Although Obama did not implement his red line in the end, his action of drawing a red line and its attempt to implement the red line actually advocated such a new international norm: If a government uses chemical weapons against its civilians, then other countries can use force against them even without the authorization of the Security Council. But so far, the scale of the "armed strike" here was still difficult to deduce.

After the trump government came to power, it launched two missile attacks against the Syrian government in 2017 and 2018 alone or jointly with Britain and France, giving the reason that the Syrian government used chemical weapons against its civilians. In this way, the new ban on chemical weapons proposed by the Obama administration, which has not been implemented, has been implemented twice by the Trump administration. In order to implement the new norm, the United States, Britain and France have tried to use relevant institutions to create and weave evidence of chemical weapons attacks launched by the Syrian government, and tried to obtain confirmation of the evidence by the United Nations Security Council. However, their actions were firmly opposed by Russia and China, and their plans did not succeed. But in any case, the United States, Britain and France practiced the new norm with practical missile attacks, and therefore further clarified the concept of "force strike" in the new norm, thus safeguarding their discourse power. This proposed new norm is essentially a new type of humanitarian intervention norm, which focuses on the quality of injury rather than the quantity of injury.

China, Russia and other countries have not completely opposed the new international chemical weapons ban proposed by the United States, Britain and France (in fact, when Russia proposed "chemical weapons for peace", it acquiesced in the new norm proposed by Obama in action. Here, Russia lost points in the maintenance of its own diplomatic discourse system). There are two main points that they strongly oppose: The first is the abuse of this norm, that is, the use of fabricated evidence of so-called chemical weapons attacks to interfere with other countries by force in order to achieve their own political purposes; The second is the unilateral armed attack contained in the new norm, that is, to carry out limited force strikes against the so-called chemical weapons users they identify without the authorization of the Security Council.
A series of actions taken by the United States, Britain and France under the pretext of the chemical weapons attacks in Syria are fundamentally based on human rights principles, while China, Russia and other countries are still based on the sovereignty principle (the identification of those responsible for chemical weapons attacks in Syria lacks sufficient evidence and is too arbitrary. Under such circumstances, forcibly attacking the Syrian government without the authorization of the Security Council is a serious violation of Syrian sovereignty) to fight against these behaviors. In fact, sovereignty principle and human rights principle are very important principles for both sides of the game. The United States, Britain and France assumed that "human rights principle takes precedence over sovereignty principle" in the game, while China and Russia did the opposite, assuming that "the principle of sovereignty takes precedence over the principle of human rights". Therefore, the game played by the great powers around the chemical weapons attack in Syria reflects the issue of international norms, which is fundamentally the question of "which takes precedence, the principle of sovereignty or the principle of human rights".

\section{ACKNOWLEDGEMENT}

This article is part of the research work for the program "Research on the International Normative Questions of the Game between Big Powers in the Syrian Crisis" (16BGJ068) financed by the Chinese National Office for Philosophy and Social Sciences.

\section{REFERENCES}

1. 岳汉景: 《叙利亚去化武的开启、走势及地区 影响》, 《世界经济与政治论坛》2014年第1

期 ; Niklas Nováky, "The US-led Missile Strikes in Syria," Wilfried Martens Centre for European Studies, Brussels, April 2018; 马学清: 《由化 武危机看大国在叙利亚的竞争》, 载《学术探 索》2018年第12期。

2. Michael NS, Christopher MF. "Assessing U.S. Justifications for Using Force in Response to Syria's Chemical Attacks: An International Law Perspective," Journal of National Security Law \& Policy,.9, 2017; Charlotte Westbrook, "Legality and Morality in International Law: The Syria Air Strikes," International Law and Politics, 51, 2019.

3. "The Chemical Weapons Convention (CWC) at a Glance," Last Reviewed: April 2020, https://www.armscontrol.org/factsheets/cwcglance

4. Becker-Jakob U. "Countering the Use of Chemical Weapons in Syria: Options for Supporting International Norms and Institutions," NonProliferation and Disarmament Papers, No. 63, June 2019, 2; "5 Things You should Know about Chemical Weapons and International Law," Fact Sheet, August 2013, https://www.humanrightsfirst.org/resource/5- 
things-you-should-know-about-chemical-

weapons-and-international-law.

5. The White House, "Remarks by the President to the White House Press Corps," August 20, 2012, https://obamawhitehouse.archives.gov/the-pressoffice/2012/08/20/remarks-president-white-housepress-corps.

6. Tobias S, Theresa L. "Nowhere to Hide: The Logic of Chemical Weapons Use in Syria," Global Public Policy Institute (GPPi), February 2019, p.8, https://www.gppi.net/media/GPPi_Schneider_Luet kefend_2019_Nowhere_to_Hide_Web.pdf.

7. "Arab League Urges UN-backed Action in Syria," 2 Sept 2013, https:/www.aljazeera.com/news/middleeast/2013/ 09/20139118235327617.html.

8. Richard W. "Syria and Beyond: The Future of Chemical Weapons Threat," Proliferation Papers, No. 51, December 2014, 27.

9. "Arms Control and Proliferation Profile: Syria," Fact Sheets and Briefs, Last Reviewed: June 2018, https://www.armscontrol.org/factsheets/syriaprofil e\#Chemical.

10. Céline B, Oliver T. "The Chemical Weapons Ban in Troubled Waters," in Matthias Bieri, ed., CSS Analyses in Security Policy, No. 207, Center for Security Studies (CSS), ETH Zurich, April 2017, 1.

11. Jenna R. "The Politics of R2P and Inaction in Syria: U.S., Russian, and Chinese Responses," January 23, 2018, https://www.imemo.ru/files/File/ru/conf/2018/230 12018/Russo.pdf; "Russia's 12 UN Vetoes on Syria," 11 Apr. 2018, https://www.rte.ie/news/world/2018/0411/953637russia-syria-un-veto/; "UN Documents for Syria: Security Council Meeting Records," Security Council Report, https://www.securitycouncilreport.org/un_docume nts_type/security-council-meeting-

records $/$ ?ctype $=$ Syria\&cbtype $=$ syria.

12. UNSC Meeting Record, 7893rd Meeting, UN Doc. S/PV.7893, 16 November 2017.

13. Daryl K, Kelsey D. "Timeline of Syrian Chemical Weapons Activity, 2012-2019," Fact Sheets \& Briefs, Last Reviewed: March 2019, https://www.armscontrol.org/factsheets/Timelineof-Syrian-Chemical-Weapons-Activity.

14. UNSC Meeting Record, 7919th Meeting, UN Doc. S/PV.7919, 7 April 2017.

15. UNSC Meeting Record, 7922nd Meeting, UN Doc. S/PV.7922, 12 April 2017.

16. Alicia Sanders-Zakre, "What You Need to Know about Chemical Weapons Use in Syria," Updated March 14 , 2019 , https://www.armscontrol.org/blog/2018-0923/what-you-need-know-about-chemicalweapons-use-syria.

17. For more information on its statements, please see the minutes of the 8073rd, 8105th and 8107th meetings of the United Nations Security Council. The website address of the minutes of the meeting is: http://research.un.org/en/docs/sc/quick.

18. Daryl K, Kelsey D. "Timeline of Syrian Chemical Weapons Activity, 2012-2019," Fact Sheets \& Briefs, Last Reviewed: March 2019, https://www.armscontrol.org/factsheets/Timelineof-Syrian-Chemical-Weapons-Activity.

19. UNSC Meeting Record, 8228th Meeting, UN Doc. S/PV.8228, 10 April 2018

20. Niklas N. "The US-led Missile Strikes in Syria," April 2018 , https://www.martenscentre.eu/sites/default/files/pu blication-files/us-led-missile-strikes-syria.pdf.

21. UNSC Meeting Record, 8233rd Meeting, UN Doc. S/PV.8233, 14 April 2018

22. Becker-Jakob U. Countering the Use of Chemical Weapons in Syria: Options for Supporting International Norms and Institutions, NonProliferation and Disarmament Papers, No. 63, June 2019, 9.

23. UNSC Meeting Record, 8233rd Meeting, UN Doc. S/PV.8233, 14 April 2018

24. UNSC Meeting Record, 8233rd Meeting, UN Doc. S/PV.8233, 14 April 2018

25. Michael PS. Striking a Grotian Moment: How the Syria Airstrikes Changed International Law Relating to Humanitarian Intervention, Chicago Journal of International Law, Winter, 2018; 19(2):17.

26. Michael S. Syria may be Using Chemical Weapons against Its Citizens again-Here's how International Law has Changed to Help Countries Intervene, The Conversation, December 06, 2018, https://theconversation.com/syria-may-be-usingchemical-weapons-against-its-citizens-againheres-how-international-law-has-changed-to-helpcountries-intervene-108162.

27. "Syria War: What We Know about Douma 'Chemical Attack'," 10 July 2018, https://www.bbc.com/news/world-middle-east43697084.

28. The principle of charity requires us to "maximize the true value of the argumentation components and the strength of the logical relationship between the components" when reconstructing the argument. See [美]西伊、努切泰利：《逻辑思 维简易入门》, 廖备水、雷丽望、冯立荣译, 北京：机械工业出版社2013年版，第59页。

29. Michael PS. Striking a Grotian Moment: How the Syria Airstrikes Changed International Law Relating to Humanitarian Intervention, 1-29; Anders Henriksen, Trump's Missile Strike on Syria and the Legality of Using Force to Deter Chemical Warfare, Journal of Conflict \& Security Law, 2018, 23(1), 33-48.

30. Michael NS. Legitimacy versus Legality Redux: Arming the Syrian Rebels, Journal of National Security Law \& Policy, 7, 2014, 159. 
Hanjing Yue \& Ying Zhu., Sch J Econ Bus Manag, September, 2020; 7(9): 304-312 